\title{
Aryl Diazonium Modification for Improved Graphite Fibre Brush in Microbial Fuel Cell
}

\author{
(Pengubahsuaian Aril Diazonium bagi Berus Gentian Grafit yang Lebih Baik dalam Sel Bahan Bakar Mikrob)
}

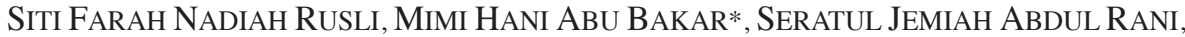 \\ LOH KEE SHYUAN \& MOHD SHAHBUDIN MASTAR
}

\begin{abstract}
Aryl diazonium salts are coupling agents that assist in molecules attachment to interfaces for sensing purposes. Despite not being fully explored and not yet widely applicable for cell-based sensors, the high stability of aryl diazonium salt formed sensing system is highly favorable in biological applications. Carbon-based electrodes are the most commonly used in aryl diazonium modification due to its post grafting stable $C$-C bond formation. Here, salt bridge based microbial fuel cells (MFCS) were used to study on the effect of aryl diazonium modification on the anode graphite fibre brush. Aryl diazonium salts were in situ generated by the diazonation of p-phenylenediamine with $\mathrm{NaNO}_{2}$ in $\mathrm{HCl}$ solution. The electrochemical performance of the aryl diazonium modified graphite brush MFC was measured and compared with the unmodified graphite brush MFC. The power output of the modified graphite brush bioanode was higher $\left(8.33 \mathrm{~W} / \mathrm{m}^{3}\right)$ than the unmodified graphite brush $\left(7.60 \mathrm{~W} / \mathrm{m}^{3}\right)$ after 20 days of operation with ferricyanide as the catholyte. After 70 days of operation using phosphate buffer solution as the catholyte, the $P_{\text {max }}$ of modified brush was three times higher $\left(0.06 \mathrm{~W} / \mathrm{m}^{3}\right)$ than of the unmodified brush $\left(0.02 \mathrm{~W} / \mathrm{m}^{3}\right)$, which indicates an enhanced binding towards the substrate that facilitates a better electron transfer between the microbial and electrode surface.
\end{abstract}

Keywords: Aryl diazonium salt; graphite fibre brush modification; microbial fuel cell

ABSTRAK

Garam aril diazonium adalah agen gandingan yang membantu dalam pelekatan molekul pada antara muka untuk tujuan penderiaan. Walaupun tidak diterokai sepenuhnya dan belum digunakan secara meluas untuk sensor berasaskan sel, kestabilan tinggi garam aril diazonium yang terbentuk adalah sistem sensor yang sangat baik dalam aplikasi biologi. Elektrod berasaskan karbon adalah yang paling biasa digunakan dalam pengubahsuaian aril diazonium kerana pembentukan ikatan C-C yang stabil di akhir cantuman. Di sini, jambatan garam berasaskan sel bahan bakar mikrob $(M F C)$ digunakan untuk mengkaji kesan pengubahsuaian aril diazonium pada berus gentian anod grafit. Garam aril diazonium dihasilkan secara in situ oleh pengasingan p-fenilenediamina dengan $\mathrm{NaNO}_{2}$ dalam larutan HCl. Prestasi elektrokimia berus grafit diubah suai aril diazonium diukur dan dibandingkan dengan berus grafit MFC yang tidak diubah suai. Hasil kuasa bioanod berus grafit yang diubah suai lebih tinggi $\left(8.33 \mathrm{~W} / \mathrm{m}^{3}\right)$ daripada berus grafit yang tidak diubah suai $\left(7.60 \mathrm{~W} / \mathrm{m}^{3}\right)$ selepas 20 hari beroperasi dengan ferrisianida sebagai katolit. Selepas 70 hari operasi menggunakan larutan fosfat sebagai katolit, $P_{\max }$ berus yang diubah suai adalah tiga kali lebih tinggi $\left(0.06 \mathrm{~W} / \mathrm{m}^{3}\right)$ daripada berus yang tidak diubah suai $\left(0.02 \mathrm{~W} / \mathrm{m}^{3}\right)$. Keputusan ini menunjukkan pengubahsuaian memberi ikatan lebih baik ke arah substrat, sekaligus memudahkan pemindahan elektron yang lebih baik antara permukaan mikrob dan elektrod.

Kata kunci: Berus gentian anod grafit; garam aril diazonium; sel bahan bakar mikrob

\section{INTRODUCTION}

A conventional MFC system consists of two chambers: An anode and a cathode, separated by a proton exchange membrane (PEM). Traditionally, MFCs were operated with a biotic anodic chamber while the cathodic chamber remains abiotic. Electricity is generated from the oxidation of organic matter by microorganisms on the anode side and the reduction of oxygen on the cathode side (Song et al. 2015). The current power outputs of practical MFCs are around $100 \mathrm{~W} / \mathrm{m}^{3}$, which is about one order of magnitude too low to be economically viable. Thus, it is necessary to study and improve several areas: Materials, microbiology, electrochemistry, and design aspects, of the system to produce trans disciplinary fundamental knowledge and progress towards credible applications.

One of the studied parts in MFC is the electrode. Generally, electrodes must have good conduction, good chemical stability, high mechanical strength, and low in cost. The electrodes act as a conductive carrier for the microorganisms, therefore necessary for an electrode to possess surface roughness, excellent biocompatibility and efficient electron transfer ability (Wei et al. 2011). The most commonly used electrode materials to date are carbon-based materials, available as carbon cloth (Zhuang 
et al. 2012), carbon paper (Sun et al. 2011), graphite felt (Song \& Jiang 2011), graphite granules (Zhang et al. 2011), and graphite fibre brush (GFB) (Lanas \& Logan 2013). The interest in using carbon-based material is due to the $\pi$ bonding between the $\mathrm{C}$ atoms. This bonding allows free movements of electrons that support the excellent conductivity (Abu Bakar et al. 2017).

Surface modification during fabrication of an electrode is sometimes made to improve bacterial adhesion as well as electron transfer (Wei et al. 2011). Recent research in MFC showed interest in treating or modifying carbon-based substrates to increase electrochemical and bioremediation performances (Picot et al. 2011). One of the methods is by using aryl diazonium salts considering its simple preparation, broad reactive functional groups and strong covalent bonding to various surfaces: polymers, biomacromolecules and nanoparticles, especially when the surface to be modified negatively charged (Abu Bakar et al. 2017). When aromatic diazonium salts $\left(\mathrm{ArN}_{2}{ }^{+} \mathrm{X}^{-}\right)$react with a surface, most of the time the diazonium group is lost and the radical (Ar) reacts with the surface.

$$
\mathrm{ArN}_{2}{ }^{+} \mathrm{Cl}^{-}+\mathrm{CuCl} \longrightarrow \mathrm{ArCl}+\mathrm{N}_{2}
$$

This grafting process involves a step known as homolytic dediazonation, a spontaneous reaction, which can be slowed down at a temperature below $5^{\circ} \mathrm{C}$. The dediazonation, however, can take place heterolytically to produce $\mathrm{Ar}^{+}$cations. $\mathrm{ArN}_{2}{ }^{+} \mathrm{X}^{-}$is readily synthesized in an acidic aqueous medium from an amine in the presence of $\mathrm{NaNO}_{2}$, and in an aprotic medium (Pinson 2012).

In a study by Guo et al. (2013), aryl diazonium salts with different functional groups were reduced to modify glassy carbon surface for the anode in MFC (Guo et al. 2013b). Their study reported that the anode surfaces were positively charged and hydrophobic after modification. The after-effect is favorable to attract particular electroactive microbes such as Geobacter, thus promotes the formation of electroactive biofilms. The difference in maximum current output obtained from different functional group modifications of $\mathrm{OH}\left(0.149 \mathrm{~mA} / \mathrm{cm}^{2}\right),-\mathrm{CH}_{3}(0.048 \mathrm{~mA} /$ $\left.\mathrm{cm}^{2}\right),-\mathrm{SO}_{3}^{-}\left(0.114 \mathrm{~mA} / \mathrm{cm}^{2}\right)$, and $-\mathrm{N}^{+}\left(\mathrm{CH}_{3}\right)_{3}(0.204 \mathrm{~mA} /$ $\mathrm{cm}^{2}$ ) is in parallel to the quantity of biomass, which is influenced by the anode surface charge and hydrophobicity. In another study by Picot et al. (2011), modified graphite with aryl diazonium salts were used as the anode in an ' $\mathrm{H}$ ' type MFC. They compared the electrochemical performance of the MFCs between the anodes from the modified graphite and the unmodified graphite under acetate saturation conditions. They discovered that the maximum power output increased until $90 \mathrm{~mW} / \mathrm{m}^{2}$ at $28 \mathrm{mC} / \mathrm{cm}^{2}$ degree of modification reaching an optimum and later decreased to less than $10 \mathrm{~mW} / \mathrm{m}^{2}$ at a higher degree of modification of $200 \mathrm{mC} / \mathrm{cm}^{2}$, even less performing than the unmodified graphite.

This article reports on the surface modification of GFB anodes with the electrochemical reduction of aryl diazonium salts. The objectives of this study were to identify a suitable method for GFB surface modification using aryl diazonium and subsequently, compare the effect of the aryl modified GFB electrodes on the power output of MFCs to the plain GFB electrodes.

\section{MATERIALS AND METHODS}

\section{ELECTRODE MODIFICATION}

Brush electrodes were fabricated using carbon fibres (PANAX35 50K, ZOLTEK) cut to a set of length and twisted with titanium wire. Each brush electrodes had a volumeaveraged up till $8 \times 10^{-6} \mathrm{~m}^{3}$. The GFB were cleaned with $50-50 \%$ of ethanol/acetone then rinsed with distilled water to dissolve organic adsorbed species (Dumas et al. 2008). Two different electrodes tested in this study: Non-modified GFB and modified GFB. Aryl diazonium salts were used as the surface modifier and were in situ generated by diazonation of $p$-phenylenediamine $(1 \mathrm{mM})$ with $\mathrm{NaNO}_{2}(1 \mathrm{mM})$ in $\mathrm{HCl}(0.5 \mathrm{M})$ solution (Liu et al. 2010). Two treatment methods used for the surface modification: 1) Spontaneous reduction, and 2) Electrochemical reduction. The spontaneous reduction method was adapted from Guo et al. (2013a). For the first method, a GFB immersed in the aryl diazonium salts solution for 1 and $3 \mathrm{~h}$ at room temperature under ambient light. The second method was adapted from Tasca et al. (2011). Aryl diazonium cation solution was kept in complete darkness in an ice bath for 5 min under a nitrogen stream and stirring. Surface modification was carried out through a series of electrochemical reduction using cyclic voltammetry (CV). Here, a three-electrode configuration was attached to a potentiostat (AUTOLAB PGSTAT128N, Utrecht, The Netherlands), with the GFB as the working electrode, platinum wire as auxiliary electrodes and $\mathrm{AglAgCl}(3 \mathrm{M} \mathrm{KCl})$ reference electrode. The electrode brush scanned from $-595 \mathrm{mV}$ to $+995 \mathrm{mV}$ (vs. $\mathrm{Ag} / \mathrm{AgCl}$ ) at a rate of $100 \mathrm{mV} / \mathrm{s}$ for 2 and 6 cycles in the aryl diazonium cation-generating solution. Each treatment was in triplicates. At the end of modification, all the GFBs were successively sonicated in ethanol, acetonitrile, deionized (DI) water for $5 \mathrm{~min}$ each to thoroughly remove the physically adsorbed species. The non-modified GFBs became the controls.

\section{REACTOR SET-UP AND OPERATION}

Two chambered MFC " $\mathrm{H}$ " type reactor configuration was setup using a clear cylindrical polyethylene container of $7.5 \mathrm{~cm}$ diameter and $12 \mathrm{~cm}$ height. Two types of MFCs were constructed based on the anode electrodes: Non-modified and surface modified GFBs, while the cathodes were nonmodified GFBs. The electrodes placed in the center of each chamber; both chambers connected by a salt bridge. The anode chamber was inoculated with $200 \mathrm{~mL}$ of fresh mud collected from the lake near Faculty of Engineering and Built Environment, UKM and filled with $100 \mathrm{~mL}$ of growth medium before sparged with nitrogen for $15 \mathrm{~min}$ to remove 
dissolved oxygen. The growth medium contained $1 \mathrm{~g} / \mathrm{L}$ of sodium acetate and $50 \mathrm{mM}$ phosphate buffer $(4.58 \mathrm{~g} / \mathrm{L}$ $\mathrm{Na}_{2} \mathrm{HPO}_{4}, 2.45 \mathrm{~g} / \mathrm{L} \mathrm{NaH}_{2} \mathrm{PO}_{4} \cdot \mathrm{H}_{2} \mathrm{O}, 0.31 \mathrm{~g} / \mathrm{L} \mathrm{NH}_{4} \mathrm{Cl}, 0.13$ $\mathrm{g} / \mathrm{L} \mathrm{KCl}, 1.0 \mathrm{~g} / \mathrm{LC}_{2} \mathrm{H}_{3} \mathrm{NaO} .3 \mathrm{H}_{2} \mathrm{O}, 12.5 \mathrm{~mL}$ Wolves mineral and $5 \mathrm{~mL}$ vitamin solution) (Logan et al. 2007). Initially, $0.1 \mathrm{M}$ potassium ferricyanide (in $20 \mathrm{mM}$ phosphate buffer) was used as catholyte for 30 days before changing to a phosphate buffer solution with a continuous air bubble. Reactors operated in batch mode at room temperature (20 $\pm 5^{\circ} \mathrm{C}$ ) and under $1 \mathrm{k} \Omega$ external resistor.

\section{ANALYSIS AND CALCULATION}

The surface electrochemical properties of the GFB electrodes were characterized by $\mathrm{CV}$ in a beaker using a conventional three- electrodes system: GFBs as working electrode, a platinum wire as an auxiliary electrode and an $\mathrm{AglAgCl}(3 \mathrm{M} \mathrm{KCl})$ reference electrode. All the $\mathrm{CV}$ experiments on the GFBs before the MFC operation were carried out in $10 \mathrm{mM}$ ferricyanide solution $\left.\left(\mathrm{Fe}(\mathrm{CN})_{6}\right]^{3-}\right)$ : $3.29 \mathrm{~g} / \mathrm{L} \mathrm{K}_{3} \mathrm{Fe}(\mathrm{CN})_{6}$ and $101 \mathrm{~g} / \mathrm{L} \mathrm{KNO}_{3}$. The $\mathrm{CV}$ conducted at a potential window between $-0.6 \mathrm{~V}$ and $+1.0 \mathrm{~V}$ (vs. Ag/ $\mathrm{AgCl})$ at $20 \mathrm{mV} / \mathrm{s}$ scan rate. The calculation for formal potential $\left(E_{f}^{0}\right)$ for each GFBs is as follows:

$$
E_{f}^{o}=\left(E_{p}^{o x}+E_{p}^{r e d}\right) / 2
$$

where $E_{p}^{o x}$ is the oxidation peak potential, and $E_{p}^{\text {red }}$ is the reduction peak potential. The cell voltage across the closed circuit was measured using a digital multimeter and recorded every $5 \mathrm{~min}$ on a personal computer through a data acquisition system (Model 2700, Keithley, USA). The current $(I)$ calculated following Ohm's law: $I=$ $U / R$, where $U$ is the measured voltage $(\mathrm{V})$ and $R$ is the external resistance value $(\Omega)$. The polarization graphs were plotted from 10 days onward by imposing potential at forward (potential decrease linearly) and reverse (potential increase linearly) sweep voltammetry (LSV) by using the potentiostat. The graph recorded at a scan rate of $10 \mathrm{mV} / \mathrm{s}$ from $0 \mathrm{~V}$ to $0.8 \mathrm{~V}$. Power $(P)$ was calculated according to $P=I U$. The $U(\mathrm{~V})$ and $P$ density $\left(\mathrm{W} / \mathrm{m}^{3}\right)$ plotted against the $I$ density $\left(\mathrm{A} / \mathrm{m}^{3}\right)$ to obtain the polarization and power density graphs, respectively. Internal resistance $\left(R_{\text {int }}\right)$ was calculated using the polarization slope method (Logan et al. 2006): $R_{\text {int }}=\Delta U / \Delta I$.

For statistical analysis, the t-test was used for the significance test calculations. The t-test is to compare the values of the means from two samples and test whether it is likely that the samples are from populations having different mean values. The t-test also tells how significant the differences are and the t-test used for this study is the two-tailed test.

\section{RESULTS AND DISCUSSION}

\section{ELECTROCHEMICAL SENSITIVITY OF THE ELECTRODE}

$\mathrm{CV}$ analysis is a convenient way to detect whether aryl diazonium has covalently bound to the GFB surface. Figure 1 shows that unmodified and modified brush electrodes showed prominent potential peaks. Comparison on the difference between the $E_{f}^{0}$ and $E^{0}$ of ferricyanide/ ferrocyanide $\left(\Delta \mathbf{E}^{0}=/ E_{f}^{0}-E^{0} /\right)$, shows that the smallest $\Delta \mathbf{E}^{0}$ delivers better current response from the reaction of electrolyte close to $E^{0}$ of ferricyanide/ ferrocyanide $\left(E^{0}\right.$ of $156 \mathrm{mV}$ vs. $\mathrm{Ag} / \mathrm{AgCl})$. The study shows that $\boldsymbol{\Delta} \mathbf{E}^{0}$ for $3 \mathrm{~h}$ modification was most deviated from $E^{0}$ up to $31 \%$, followed by both unmodified and 2-cycles at $28 \%, 1 \mathrm{~h}$ modification at $26 \%$ and 6-cycles at $23 \%$. The bigger the $\Delta \mathbf{E}^{0}$, the slower the electron transferability of the electrode, thus the electrochemical behavior of the electrode is quasi-reversible (Brownson \& Banks 2014). Electrode improvement through 6-cycles modification method became the method in this study due to the significant

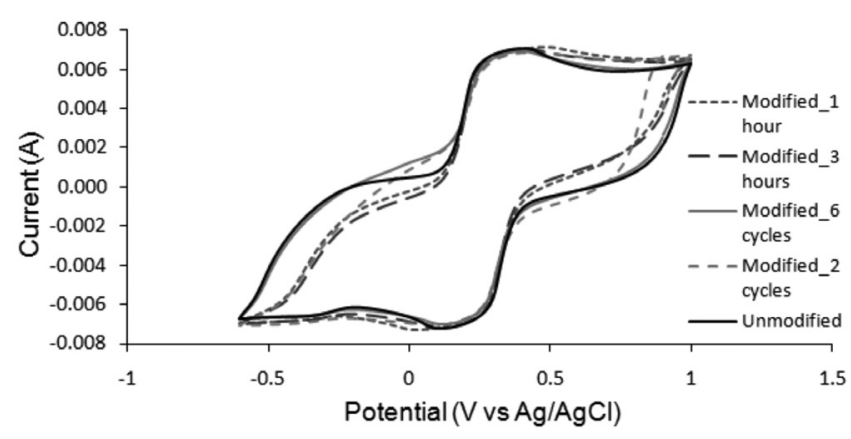

FIGURE 1. Cyclic voltammetry analyses on graphite brush with and without aryl diazonium salt modification. Each electrodes underwent three complete cycles at scan range of $20 \mathrm{mV} / \mathrm{s}$ from $-0.6 \mathrm{~V}$ to $+1 \mathrm{~V}(\mathrm{vs} \mathrm{Ag} / \mathrm{AgCl})$ in $\left.10 \mathrm{mM} \mathrm{Fe}(\mathrm{CN})_{6}\right]^{3-} / 1 \mathrm{M} \mathrm{NO}^{3-}$

The formal pontential $\left(E_{f}^{0}\right)$ obtained from the graphite brushes:

Unmodified: $112.55 \pm 8.5 \mathrm{mV}$

Spontaneous reduction (Room temperature modification):

Electrochemical reduction (Modification $<5^{\circ} \mathrm{C}$ ):

$1 \mathrm{~h}: 116.05 \pm 4.5 \mathrm{mV}$

2 cycles: $111.82 \pm 7.6 \mathrm{mV}$

$3 \mathrm{~h}: 107.27 \pm 1.8 \mathrm{mV}$

6 cycles: $120.33 \pm 7.8 \mathrm{mV}$ 
statistical difference (t-test, $p<0.05,(p=0.001$ at two-tailed test)) based on $\Delta \mathbf{E}^{0}$ calculated in this study.

\section{FABRICATED GRAPHITE FIBRE BRUSH AS AN ELECTRODE IN A MICROBIAL FUEL CELL}

Batch experiments were carried out to measure the power output of the MFCs. Figure 2 shows the current density produced during the first 51 days when using potassium ferricyanide as catholyte. After three days of start-up, both MFCs though with different GFB treatments showed a current density up to $0.02 \pm 0.002 \mathrm{~mA}$. Afterward, MFCs from modified GFBs gave an upward trending before it became stable at $0.033 \pm 0.002 \mathrm{~mA}$. Meanwhile, MFCs from unmodified GFBs showed upward trending up to 0.026 $\pm 0.009 \mathrm{~mA}$. The comparison on the current generated at start-up shows that the surface modification with aryl diazonium to the GFBs had generated higher current in comparison to the unmodified GFBs. This finding could be due to the successful modification of aryl diazonium as reported in CV analysis, had attracted the exoelectrogen bacteria for adhesion due to the existence of positively charged groups on the GFB's surface as mentioned in Abu Bakar et al. (2017).

After 30 days, the catholyte changed to a phosphate buffer solution and the current obtained for the first 5 days are shown in Figure 3. The current decreased to less than $0.025 \mathrm{~mA}$ after the change in catholyte. The slight decreases in current production after catholyte change shows that the current production is affected by the concentration of the electrolyte solution.

\section{POWER PERFORMANCE DETECTED IN MICROBIAL FUEL CELL}

The power performances of the MFCs were evaluated through a polarization curve. Figure 4 shows different performances of modified and unmodified GFBs when using ferricyanide as catholyte. Table 1 simplifies the maximum power density and current density obtained. The result obtained showed that the modification of the

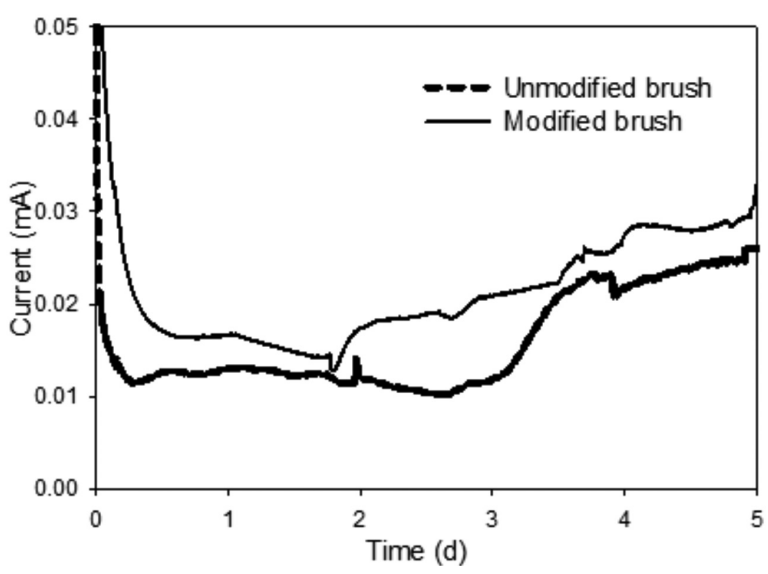

FIGURE 2. The cell current density at start-up of operation with $0.1 \mathrm{M}$ potassium ferricyanide as catholyte

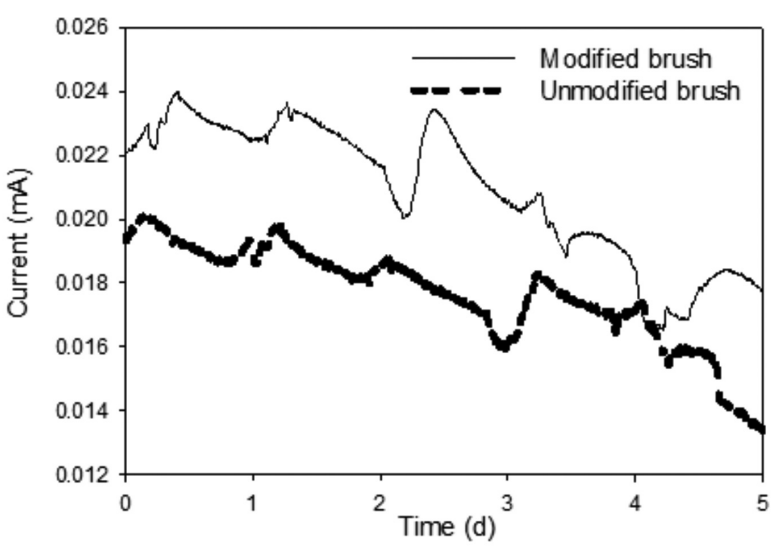

FIGURE 3 . The cell current density when the catholyte changed to air-bubbled-0.05 $\mathrm{M}$ phosphate buffer

graphite brush and the catholyte used affects the maximum power and current densities. At day 10 of operation, the maximum power density for the unmodified brush was slightly higher than that of the modified brush, while the current modified brush gave higher in current density and the internal resistance. At day 20, the power and the current density of the modified brush were higher than the unmodified brush, indicating that the performance of the MFC system enhances with the modification of the brush.

The modified brush MFC obtained the highest maximum power and current densities of $8.33 \mathrm{~W} / \mathrm{m}^{3}(0.82$ $\left.\mathrm{mW} / \mathrm{m}^{2}\right)$ and $40.4 \mathrm{~A} / \mathrm{m}^{3}\left(4 \mathrm{~mA} / \mathrm{m}^{2}\right)$, respectively, when using ferricyanide as catholyte at day 20 (Figure 4(b)). At day 70 , the MFCs with phosphate buffer solution catholyte obtained the lowest performance in comparison to when the MFCs were running with ferricyanide catholyte; with power densities obtained for unmodified and modified brush were 0.02 and $0.06 \mathrm{~W} / \mathrm{m}^{3}$, respectively (Figure 5). The low power performance proves that the ferricyanide as a suitable electron acceptor to increase the power density and therefore further enhances the performance of the MFC. Regardless of the different catholyte used in the MFC systems, the aryl diazonium modified brush MFC can obtain a higher maximum power output as well as current density. The obtained results further prove that the anode surface charge and hydrophobicity due to the aryl diazonium modification influence the enhanced in the performance of MFC, as to what was experienced by Guo et al. (2013b).

The internal resistance is also a factor that affects the production of power in MFCs. The internal resistance was measured based on the slope analysis of the polarization curve. The internal resistance for the unmodified and modified brushes was not much of a difference. However, the difference in internal resistance was noticeable when using different catholyte. The internal resistance was higher with a phosphate buffer solution, in comparison to with ferricyanide. The internal resistance increased in the low concentration of electrolyte solutions and the relatively low internal resistance with ferricyanide was 

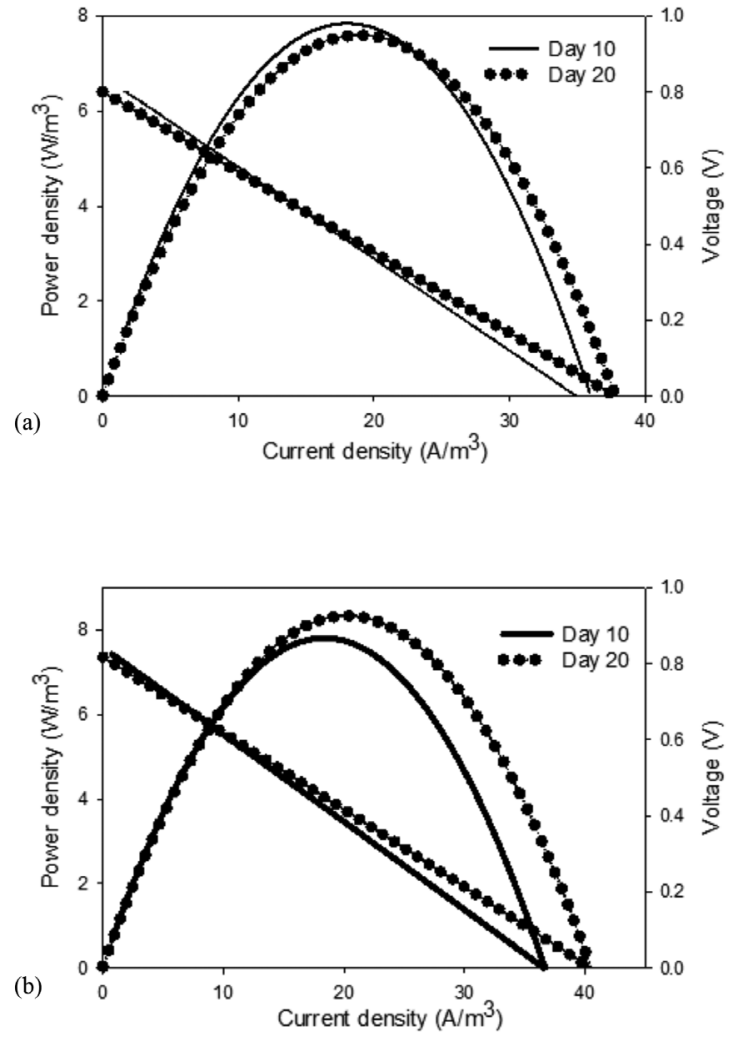

FIGURE 4. Polarization and power curves for unmodified (a) and modified (b) graphite brushes MFC with $0.1 \mathrm{M}$ potassium ferricyanide as catholyte. Data were recorded for day 10 and day 20

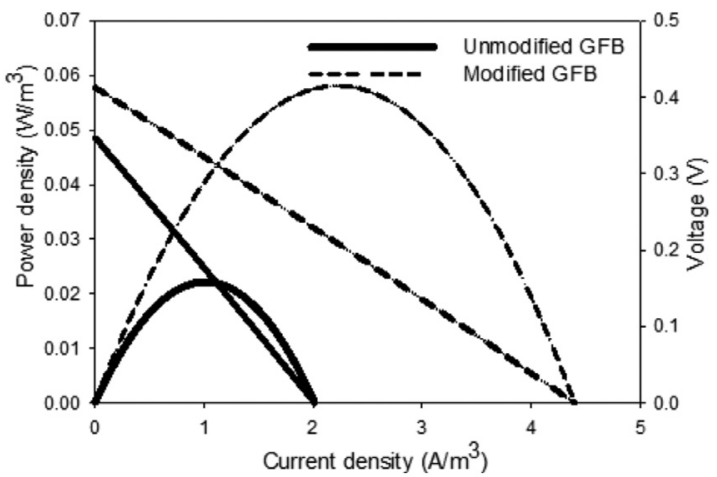

FIGURE 5. Polarization and power curves for modified and unmodified graphite brushes with $0.05 \mathrm{M}$ phosphate buffer solution as catholyte. Data were recorded on day 70

TABLE 1. The performance of unmodified and modified graphite brushes with different catholytes

\begin{tabular}{|c|c|c|c|c|}
\hline Types of catholytes & $\begin{array}{l}\text { Types of graphite } \\
\text { fibre brushes }\end{array}$ & $\begin{array}{l}\text { Maximum power density } \\
\qquad\left(P_{\max }\right)\left(\mathrm{W} / \mathrm{m}^{3}\right)\end{array}$ & $\begin{array}{l}\text { Maximum current } \\
\text { density }\left(I_{\max }\right)\left(\mathrm{A} / \mathrm{m}^{3}\right)\end{array}$ & $\begin{array}{l}\text { Internal resistance } \\
\qquad\left(R_{\text {int }}\right)(\Omega)\end{array}$ \\
\hline \multicolumn{5}{|l|}{ Ferricyanide: } \\
\hline & $\begin{array}{l}\text { Unmodified } \\
\text {-Day } 10\end{array}$ & 7.84 & 35.9 & 2857 \\
\hline & $\begin{array}{l}\text { Unmodified } \\
\text {-Day } 20\end{array}$ & 7.60 & 37.8 & 2703 \\
\hline & $\begin{array}{l}\text { Modified } \\
\text {-Day } 10\end{array}$ & 7.81 & 36.7 & 2778 \\
\hline & $\begin{array}{l}\text { Modified } \\
\text {-Day } 20\end{array}$ & 8.33 & 40.4 & 2500 \\
\hline \multirow[t]{2}{*}{ Phosphate Buffer: } & Unmodified & 0.02 & 2.04 & 18750 \\
\hline & Modified & 0.06 & 4.40 & 12500 \\
\hline
\end{tabular}


probably due to the availability of sufficient electron acceptors that keep the cathode potential stable and continuous over a cycle, and therefore the potential reduction of the whole cell abstained. The power and current densities reported were relatively lower than what was achieved from a previous report (Picot et al. 2011a). The results obtained were lower maybe due to the difference in reactor configurations, particularly the separator used in this system. Compared to the previous report, which applied Nafion as a separator, this study used the salt bridge, which is more simple and inexpensive. However, salt bridge generates low power density due to its high internal resistance (Li et al. 2011), which also proven from this study. A better reactor configuration could further increase the power performance of this modified brush MFC.

\section{CONCLUSION}

A modification procedure of graphite brushes for MFC has been carried out by electrografting in an ice bath of aryl diazonium salts. For maximum improvement of anodic microbial electrocatalysis in MFC, it is essential to introduce a surface modifier with physicochemical properties promoting the development of an efficient electroactive biofilm. The power and current densities were the highest; $8.33 \mathrm{~W} / \mathrm{m}^{3}$ and $40.4 \mathrm{~A} / \mathrm{m}^{3}$, respectively, after 20 days of operation using ferricyanide catholyte and modified brush MFC. This study shows that the performance of MFC can be significantly improved provided the amount of modifier introduced onto the surface be controlled and optimized.

\section{ACKNOWLEDGEMENTS}

The authors gratefully acknowledge the support given for this work by FRGS/1/2014/TK06/UKM/03/1 and GUP2015-036 from Universiti Kebangsaan Malaysia (UKM). The authors would like to extend their appreciation to the staffs and technicians of the Fuel Cell Institute and the Faculty of Science and Technology of UKM for their support.

\section{REFERENCES}

Abu Bakar, M.H., Pasco, N.F., Gooneratne, R. \& Kim, B.H. 2016. Cellobiose dehydrogenase/epoxy-graphite composite with aryl diazonium reduction for lactose detection. Jurnal Teknologi 3: 97-105.

Brownson, D.A.C. \& Banks, C.E. 2014. The Handbook of Graphene Electrochemistry. London: Springer-Verlag.

Dumas, C., Basseguy, R. \& Bergel, A. 2008. Microbial electrocatalysis with Geobacter sulfurreducens biofilm on stainless steel cathodes. Electrochimica Acta 53(5): 24942500.

Guo, K., Chen, X., Freguia, S. \& Donose, B.C. 2013 a. Spontaneous modification of carbon surface with neutral red from its diazonium salts for bioelectrochemical systems. Biosensors and Bioelectronics 47: 184-189.

Guo, K., Freguia, S., Dennis, P.G., Chen, X., Donose, B.C., Keller, J., Gooding, J.J. \& Rabaey, K. 2013b. Effects of surface charge and hydrophobicity on anodic biofilm formation, community composition and current generation in bioelectrochemical systems. Environmental Science and Technology 47(13): 7563-7570.

Lanas, V. \& Logan, B.E. 2013. Evaluation of multi-brush anode systems in microbial fuel cells. Bioresource Technology 148: 379-385.

Li, W.W., Sheng, G.P., Liu, X.W. \& Yu, H.Q. 2011. Recent advances in the separators for microbial fuel cells. Bioresource Technology 102(1): 244-252.

Liu, G., Chockalingham, M., Khor, S.M., Gui, A.L. \& Justin Gooding, J. 2010. A comparative study of the modification of gold and glassy carbon surfaces with mixed layers of in situ generated aryl diazonium compounds. Electroanalysis 22(9): 918-926.

Logan, B., Cheng, S., Watson, V. \& Estadt, G. 2007. Graphite fiber brush anodes for increased power production in air-cathode microbial fuel cells. Environmental Science and Technology 41(9): 3341-3346.

Logan, B.E., Rabaey, K., Hamelers, B., Aelterman, P., Freguia, S. \& Verstraete, W. 2006. Critical review microbial fuel cells: Methodology and technology. Environmental Science \& Technology 40(17): 5181-5192.

Picot, M., Lapinsonnière, L., Rothballer, M. \& Barrière, F. 2011. Graphite anode surface modification with controlled reduction of specific aryl diazonium salts for improved microbial fuel cells power output. Biosensors and Bioelectronics 28(1): 181-188.

Pinson, J. 2012. Attachment of organic layers to materials surfaces by reduction of diazonium salts. In Aryl Diazonium Salts: New Coupling Agents in Polymer and Surface Science, edited by Chehimi, M.M. Germany: Wiley. VCH Verlag GmbH \& Co. pp. 1-35.

Song, H., Zhu, Y., Li, J., Zhu, Y. \& Li, J. 2015. Electron transfer mechanisms, characteristics and applications of biological cathode microbial fuel cells - A mini review. Arabian Journal of Chemistry https://doi.org/10.1016/j.arabjc.2015.01.008.

Song, T.S. \& Jiang, H.L. 2011. Effects of sediment pretreatment on the performance of sediment microbial fuel cells. Bioresource Technology 102(22): 10465-10470.

Sun, J., Bi, Z., Hou, B., Cao, Y.Q. \& Hu, Y.Y. 2011. Further treatment of decolorization liquid of azo dye coupled with increased power production using microbial fuel cell equipped with an aerobic biocathode. Water Research 45(1): 283-291.

Tasca, F., Harreither, W., Ludwig, R., Gooding, J.J. \& Gorton, L. 2011. Cellobiose dehydrogenase aryl diazoniunn modified single walled carbon nanotubes: Enhanced direct electron transfer through a positively charged surface. Analytical Chemistry 83(8): 3042-3049.

Wei, J.,Liang, P. \& Huang, X. 2011. Recent progress in electrodes for microbial fuel cells. Bioresource Technology 102(20): 9335-9344.

Zhang, G.D., Zhao, Q.L., Jiao, Y., Zhang, J.N., Jiang, J.Q., Ren, N. \& Kim, B.H. 2011. Improved performance of microbial fuel cell using combination biocathode of graphite fiber brush and graphite granules. Journal of Power Sources 196(15): 6036-6041.

Zhuang, L., Yuan, Y., Yang, G. \& Zhou, S. 2012. In situ formation of graphene/biofilm composites for enhanced oxygen reduction in biocathode microbial fuel cells. Electrochemistry Communications 21: 69-72. 
Siti Farah Nadiah Rusli, Mimi Hani Abu Bakar*, Loh Kee Shyuan \& Mohd Shahbudin Mastar

Fuel Cell Institute

Universiti Kebangsaan Malaysia

43600 UKM Bangi, Selangor Darul Ehsan

Malaysia

Seratul Jemiah Abdul Rani

Faculty of Science and Technology

Universiti Kebangsaan Malaysia

43600 UKM Bangi, Selangor Darul Ehsan

Malaysia
Mohd Shahbudin Mastar

Faculty of Engineering and Build Environment

Universiti Kebangsaan Malaysia

43600 UKM Bangi, Selangor Darul Ehsan

Malaysia

*Corresponding author; email: mimihani@ukm.edu.my

Received: 30 May 2018

Accepted: 18 September 2018 